\title{
Quality of Life of Physical Education Students from a Private Institution in the Western Zone of Rio de Janeiro
}

\section{Qualidade de Vida dos Estudantes de Educação Física de uma Instituição Privada da Zona Oeste do Rio de Janeiro}

\author{
Felipe Triani*a, Leandro de Abreu Villar ${ }^{\mathrm{b}}$; Marcelo Ferreira da Silva ${ }^{\mathrm{b}}$; Paulo Sérgio Pimentel ${ }^{\mathrm{a}}$ \\ ${ }^{a}$ State University of Rio de Janeiro, Graduate Program in Exercise and Sports Science. RJ, Brazil. \\ ${ }^{b}$ Gama and Souza College, Institute of Biosciences, Physical Education Course. RJ, Brazil. \\ *E-mail: felipetriani@gmail.com \\ Recebido em: 05/02/19 \\ Aprovado em: 31/07/19
}

\begin{abstract}
Quality of Life is an indispensable measure to measure the conditions in which people of a certain social group live. Thus, considering that the reality of physical education students of a private institution is to work during the hours that are not in class, that is, they accumulate work and study activities, implying the absence of time to take care of health and, considering also the lack of studies in this line of research is that this research is persented. Thus, the objective of the present study was to know and analyze the level of quality of life of a group of students of physical education in Rio de Janeiro. A total of 100 physical education students between 18 and 28 years of age from the western zone of Rio de Janeiro who answered the questionnaire SF-36 participated. As a result, it was observed $91 \%$ level of functional capacity, $74 \%$ for the physical and emotional domains, $57 \%$ for mental aspects, $52 \%$ for vitality, $47 \%$ for general health, $24 \%$ of pain and $2 \%$ regarding social aspects. However, health professionals, due to precarious socioeconomic needs and working conditions, tend to have their own quality of life compromised to the detriment of professional practice.
\end{abstract}

Keywords: Quality of Life. Physical Exertion. Health Profile.

\section{Resumo}

A Qualidade de Vida constitui uma medida indispensável para mensurar as condições em que pessoas de um determinado grupo social vivem. Dessa forma, considerando que a realidade de estudantes de educação fisica de instituição privada é trabalhar no horário que não estão em aula, ou seja, acumulam as atividades de trabalho e estudo, implicando à ausência de tempo para cuidar da saúde e, considerando ainda a carência de estudos nessa linha de investigação é que essa pesquisa se apresenta. Dessa maneira, o objetivo do presente estudo foi conhecer e analisar o nível de qualidade de vida de um grupo de estudantes de Educação Física do Rio de Janeiro. Participaram 100 estudantes de Educação Física entre 18 e 28 anos da zona oeste do Rio de Janeiro que responderam ao questionário SF-36. Como resultado, percebeu-se um nivel de $91 \%$ quanto à capacidade funcional, 74\% para os domínios aspectos físicos e emocionais, 57\% em relação aos aspectos mentais, $52 \%$ à vitalidade, $47 \%$ ao estado geral de saúde, $24 \%$ de dor e $2 \%$ no que se refere aos aspectos sociais. Embora profissionais da saúde, devido às necessidades socioeconômicas e condições de trabalho precarizadas, tendem a ter sua própria qualidade de vida comprometida em detrimento da prática profissional.

Palavras-chave: Qualidade de Vida. Esforço Físico. Perfil de Saúde.

\section{Introduction}

Quality of life can be understood as the form that the subject perceives his or her position in life, in the cultural perspective and in the system of values in which the same is inserted, as well as in relation to their goals, expectations, standards and concerns ${ }^{1}$.

Portugal et al. ${ }^{2}$ defines quality of life as the level of basic and supplementary conditions of the human being. These conditions involve the physical, mental, psychological and emotional well-being, social relationships, such as family and friends, and also the health, education and other parameters that affect the human life.

According to Martteli and Delbim ${ }^{3}$ quality of life is a determining factor to consider the health, since the improvement of health is subject to increased quality of life. The author emphasizes that the quality of life depends on factors such as disease, sanitation, nutrition, exercise, air quality in the environment in which he or she resides, water quality in the residence and stress level.

A research conducted by Palma et al. ${ }^{4}$, with the objective to investigate health problems of physical education teachers related to occupation, performed with 149 physical education teachers, revealed that the agents of such categories, in some cases, exceeds 60 hours of journey of weekly working time, a large part complains of pain, have little time for food and do not perform exercises, with risk factors for the occurrence of minor psychiatric disorders, that is, the working conditions testify against the teachers' health.

Palma $^{5}$ published a review on the health of physical education teachers. On occasion he adds that professionals 
in this category make up a load of work exceeding 50 hours per week and, in some cases, they exceed 70 hours. In addition, working in several places and spending time with displacement are characteristics present in the lives of these agents. These factors have generated professional dissatisfaction and many health problems, causing suffering to teachers due to precarious work.

It should be noted, therefore, that there is some evidence on this category when the context makes reference to the professionals of the area, however, there is an epistemological gap when the studies with scholars of physical education that are also have their quality of life compromised with the conditions of the area, because many times, studying in the daytime or night time and working against the shift schedule of classes, and lack of time, use of time for food and leisure for study or fulfill their academic obligations. Thus, considering the importance to study that group is that this investigation aims at analyzying the level of quality of life of physical education students of Rio de Janeiro.

\section{Material and Methods}

In order to meet the objective of the research, a crosssectional study was carried out. SF-36 questionnaire was used, composed of 36 items, composing 8 dimensions, namely: functional capacity, physical aspects, pain, general health status, vitality, social aspects, emotional aspects and mental health. For each student, and for each of the dimensions a score was obtained to apply an escalation of measurement with values from 0 (more commitment) to 100 (no commitment).

The sample size was defined considering the following criteria: population of 208 individuals, sampling error of 5 percentage points, a confidence interval of $95 \%$ and $50 \%$ presumed prevalence of $50 \%$, being stipulated 87 subjects. Thus, of the total number of students in a Physical Education course of the West Zone of Rio de Janeiro, of both sexes, aged between 18 and 38 years, 100 students participated on a voluntary basis. A descriptive statistic was performed illustrating prevalence in the qualification of each stratum in percentage terms.

All students participated as volunteers and signed the informed consent form, being respected the ethical and legal criteria in studies involving human beings accordance with the Law 466 of 2012. It should be noted that the research was approved by the Research Ethics: CAAE of 41355114.3.0000.5283.

\section{Results and Discussion}

After the data collection and tabulation, the percentage of each domain was used as a parameter for the analysis of the results of the graph of Figure 1.
Figure 1 - Percentage of Quality of Life distributed by domais

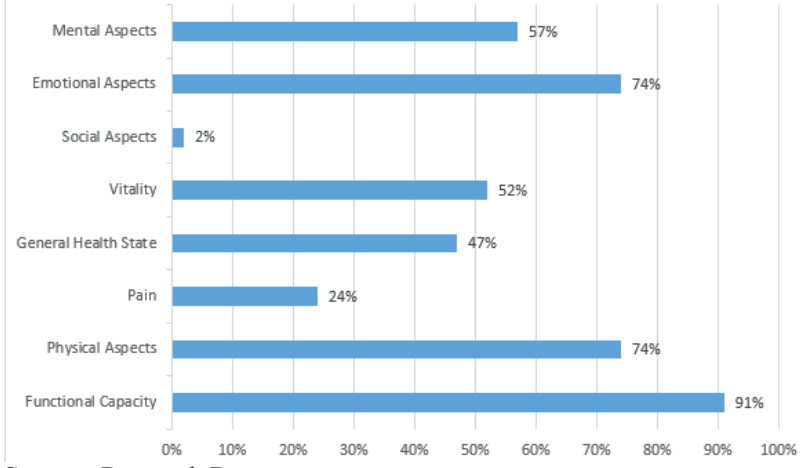

Source: Research Data.

Thus, the objective of the present study was to know and analyze the level of quality of life of a group of students of physical education in Rio de Janeiro. As a result, it was observed $91 \%$ level of functional capacity, $74 \%$ for the physical and emotional domains, 57\% for mental aspects, $52 \%$ for vitality, $47 \%$ for general health, $24 \%$ of pain and $2 \%$ regarding social aspects.

The emotional aspects presented an average of $70 \%$ of the total sample. This result is similar to a previous study ${ }^{7}$, which comprised 39,667 young people between 18 and 24 years in the city of Pelotas, on which occasion was found to be $79.2 \%$ in the field emotional aspects. These aspects that have association with the use of tobacco and alcohol, in this way, as the students, in large part, who do not use these substances showed high level in this field.

Janser et al. ${ }^{7}$ also demonstrate a good level in mental aspects (74\%), contrary to the findings of research on screen that resulted in $57 \%$. In this respect, studies suggest an association between low level in the mental domain and common mental disorders ${ }^{8}$. In this sense, although the results are not alarming rates yet, it is necessary to pay attention to this aspect that may suffer from the influence of the high number of hours in a journey of work/internship in which students subject themselves to remain enrolled in private institution.

When it comes to social aspects the results of the present study contradicts previous studies. The results found by Luna et al. ${ }^{9}$, who evaluated 104 academics of the physical education course, was found satisfactory. In addition to this, another study ${ }^{10}$ performed with 825 nursing students also showed satisfactory levels for this domain. It should be noted that the appropriate level of social aspects is recommended to increase the quality of life of subjects, alarming the low level found in this research.

Vitality has been an indicator whose result has presented low level in previous studies ${ }^{11}$. Paro and Bittencourt ${ }^{12}$ assessed 630 students of the courses of nursing, pharmacy, SpeechLanguage Pathology and medicine of a public institution and the vitality was the smallest indicator among the evaluated for quality of life, $48 \%$ on average. Thus, although the results found in this research are higher $(52 \%)$ in relation to previous 
studies, considering the importance of vitality in the life of the student in training and future health professional, this value is relatively low.

The general state of health was an aspect that had a level below the expected (47\%). This result consistent with the hypothesis that the fact that students have fewer hours of sleep, dedication to leisure, food and exercise, on account of the double shift between work and/or internship and graduation, tend to have the health compromised, as pointed Palma $^{5}$, in relation to the professionals in this area. These findings are different from other courses studied ${ }^{12}$, as nursing (63\%), pharmacy (71\%), speech therapy (61\%), medicine (68\%), reinforcing the hypothesis that agents in the area of physical education have the quality of life compromised by the precarious working conditions.

In relation to pain the result of $24 \%$ was found. This finding is consistent with the study of Palma et al. ${ }^{4}$ who identified the presence of high pain in a group of professionals of physical education and association as hours of sleep, food and practice of exercises. In previous studies with young people this domain has been presented with an average of $75 \%{ }^{7}$, however, in elderly individuals this number falls to $54 \%{ }^{13}$.

The functional capacity (91\%) and physical aspects (74\%) was highest level domain of quality of life of the group. This result is similar to the findings of Luna et al. ${ }^{9}$, as well as Aurelio et al. ${ }^{14}$ which, by means of a cross-sectional study, evaluated 64 physical education professionals and found the highest level for this field. Although the findings are similar, the highest level in this domain can be influenced by the knowledge of the practice of physical activity and its benefits.

It is worth noting that this study was developed with a group of 100 students in a physical education course, because the remaining 108 refused to participate, or completed the questionnaire in an inappropriate manner. In this sense, these results need to be relativized and should not be extrapolated to other populations, since the study was limited to an institution.

\section{Conclusion}

It was observed that in some areas of the quality of life of the students of the Physical Education Course, that comprised the sample, is really affected below the recommendations considered for health. It is important to highlight that these scholars, future professionals who have, among a universe of goals, to promote the quality of life of the population, be attentive to their own health.

\section{References}

1. The whoqol group. The World Health Organization quality of life assessment (WHOQOL): position paper from the World Health Organization. Soc Sci Med 1997;41:1403-10.

2. Portugal EMM, Sousa LA, Vasconcelos PG. Efeito do envelhecimento sobre a qualidade de vida de praticantes de atividades físicas. In.: Triani FS, Pimentel PS. Esporte, Educação física e sociedade. Rio de Janeiro: Autografia; 2016.

3. Martelli A, Delbim LR. Arborização urbana: percepção dos acadêmicos de educação física da Faculdade FMG Mogi Graçu - SP. J Health Sci 2017;19(2):154-9. doi: 10.17921/2447-8938.2017v19n3p154-159

4. Palma A, Jardim S, Luiz RR, Silva Filho JF. Trabalho e saúde: o caso dos professores de educação física que atuam em academias de ginástica. Cad IPUB 2007;8(1):11-30.

5. Palma A. E como segue a saúde dos professores de educação física? Corpus Scie 2014;10(2):1-15.

6. Severino AJ. Metodologia do trabalho científico. São Paulo: Cortez; 2007.

7. Jansen K, Mondin TC, Ores LC, Souza LDM, Konradt CE, Pinheiro RT, et al. Transtornos mentais comuns e qualidade de vida em jovens: uma amostra populacional de Pelotas, Rio Grande do Sul, Brasil. Cad Saúde Pública 2011;27(3):440-8. doi: 10.1590/S0102-311X2011000300005

8. Basu D. Quality of life issues in mental health care: past, present and future. German J Psychiatr 2004;7(1):35-43.

9. Luna AA, Molari M, Primo SH, Bispo NNC, Ossada VAY, Costa VS. Caracterização do estilo de vida de universitários do ensino superior a distância. J Health Sci 2018;20(1):40-4. doi: 10.17921/2447-8938.2018v20n1p40-44

10. Saupe R, Nitche EA, Cestari ME, Giorgi MDM, Krahl M. Qualidade de vida dos acadêmicos de enfermagem. Rev Latinoam Enferm 2004;12(4):636-42. doi: 10.1590/S010411692004000400009

11. Raj SR, Simpson CS, Hopman WM, Singer MA. Healthrelated quality of life among final-year medical students. CMAJ 2000;162(4):509-10.

12. Paro CA, Bittencourt ZZLC. Qualidade de vida de graduandos da área da saúde. Rev Bras Educ Méd 2013;17(3):365-35.

13. Pimenta FAP, Simil FF, Tôrres HOG, Amaral CFS, Rezende CF, Coelho TO, et al. Avaliação da qualidade de vida de aposentados com a utilização do questionário SF-36. Rev Assoc Med Bras 2008;54(1):55-60. doi: 10.1590/S010442302008000100021.

14. Afonso JA, Ferreira EF, Babadó AC, Oliveira RAR. Nível de atividade física dos professores de educação física nas academias de Ubá-MG. Rev Bras Presc Fis Exer 2017;11(66):293-300. 